\title{
Analysis of chrysoberyl
}

\section{Awdejew}

To cite this article: M. Awdejew (1843) Analysis of chrysoberyl, Philosophical Magazine Series 3, 22:147, 501-502, DOI: 10.1080/14786444308636435

To link to this article: http://dx.doi.org/10.1080/14786444308636435

册 Published online: 01 Jun 2009.

Submit your article to this journal $\pi$

LII Article views: 4

Q View related articles $₫$ 
firmed the suspicion, but has proved that it contains arsenic acid, peroxide of iron and lime, and that it is a double arseniate, differing in its characters and composition from the previously known arsenintes.

The proportions of its constituents are as follows:-

$$
\begin{array}{lr}
\text { Arsenic acid } \ldots \ldots \ldots \ldots & 34.26 \\
\text { Oxide of iron } \ldots \ldots \ldots \ldots & 41 \cdot 31 \\
\text { Oxide of manganese } \ldots \ldots & 1.29 \\
\text { Lime } \ldots \ldots \ldots \ldots \ldots \ldots \ldots & 8.43 \\
\text { Silica } \ldots \ldots \ldots \ldots \ldots \ldots \ldots & 4 \cdot 04 \\
\text { Potash } \ldots \ldots \ldots \ldots \ldots \ldots & 0.76 \\
\text { Water } \ldots \ldots \ldots \ldots \ldots \ldots & 8 \cdot 75 \\
\hline
\end{array}
$$

which may be represented by the formula

$$
3 \mathrm{~F}^{\sim} \mathrm{Ar}+\mathrm{CAr} \mathrm{Ar}^{2}+\mathbf{3 A q} \ldots+\mathrm{S} \text {. }
$$

In this formula, I have considered the gelatinous silica as foreign to the mineral. The analysis of the limestone of Champigny, near Paris, which contains 10 of every 100 of silica soluble in acids, without the smallest admixture of alumina, that of the green grit of Vouziers, given by M. Sauvage in his important work on the Geology of the Ardennes, which shows that this rock contains 56 of every 100 of silica soluble in a solution of potash, prove with certainty that gelatinous silica is mechanically mixed with minerals, the definite proportions of which clearly show that they contain no combined silica. Silica frequently occurs in solution in the same waters that deposit carbonate of lime; it appears that the same has occurred with the mineral from Romaneche, which has all the characters of a concretion, intermixed with gelatinous silica.

Arsenic and iron being the two elements of this new substance, I have given it the name of arsenio-siderite, which designates them.

The arsenio-siderite forms concretionary fibrous masses, which adhere to the surfaces of the tubercles of manganese; these fibres, which are large and distinct, may be separated like those of hard asbestus : it is tender and readily yields to the fingers. Its colour is yellowish-brown, which deepens by exposure to the air. It is very fusible by the blowpipe, and exhibits the reactions of both arsenic and iron. Its specific gravity is 3.52.-Ann. de Chim. Mars 1843.

ANALYSIS OF CHRYSOBERYL. BY M. AWDEJEW.

The author of these analyses remarks, that few minerals have afforded more variable results than the chrysoberyl. Klaproth and Arfwedson considered it to be a silicate of alumina; Seybert first proved it to contain glucina; he considered the chrysoberyl as containing silicate of alumina, and aluminate of glucina. Thomson stated that it contained no alumina, which has been confirmed by the analysis of M. H. Rose.

M. Awdejew examined two varieties of chrysoberyl, one from Brazil, and the other from Ural; the latter has been described by M. G. Rose.

Chrysoberyl from Brazil.-This mineral was in the state of yellow 
transparent crystals of the size of a nut; its density was $3 \cdot 733$. It was pulverized in a steel mortar and fused with bisulphate of potash. The free mass was completely dissolved in water, which proves the absence of silica. The solution contained traces of alumina, and was precipitated by excess of ammonia; the oxides thus precipitated were dissolved in hydrochloric acid, and the solution was decomposed in the cold by a solution of potash ; the oxide of iron precipitated was again dissolved in hydrochloric acid, and then precipitated by ammonia ; the glucina was separated by Gmelin's process, by boiling the solution much diluted; from the solution afterwards acidulated by hydrochloric acid, the alumina was precipitated by ammonia. The mean of two analyses gave

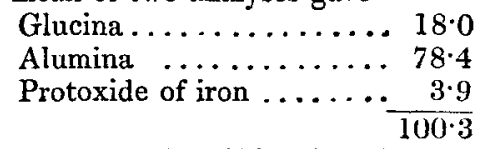

Chrysoberyl from the Ural.-This mineral contained traces of the oxides of copper and lead, which were separated by passing sulphuretted hydrogen into the solution obtained after the action of the bisulphate of potash; in other respects the analysis was conducted as above, except that the glucina being treated with a mixture of carbonate and nitrate of potash, a little oxide of chromium was separated from it; the chromic acid was reduced to the state of protoxide of chromium by means of hydrochloric acid, and then precipitated by ammonia. 100 parts yielded-

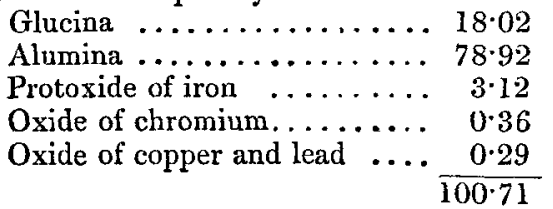

Regarding this mineral as an aluminate of glucina, it would be composed of

$$
\begin{aligned}
& \text { Alumina ............ 80.25 } \\
& \text { Glucina } \ldots \ldots \ldots \ldots \ldots \ldots \cdot \frac{19 \cdot 75}{100^{\circ}} \\
& \text { Ann. de Chim. et de Phys., Fevrier } 1843 .
\end{aligned}
$$

SOLUTION OF AN EQUATION, BY JAMES COCKLE, B.A., TRINITY COLLEGE, CAMBRIDGE.

To the Editors of the Philosophical Magazine. Gentuemen,

I have taken the liberty of sending to you a solution of the equation

$$
\begin{aligned}
& x^{3}+a x+b=0 \ldots \ldots \ldots \ldots \ldots \ldots \ldots \ldots \\
& x^{3}+3 p x^{2}+3 p^{2} x=-b \ldots \ldots \ldots \ldots
\end{aligned}
$$

Assume

Subtract (1.) from (2.) and divide by $3 p x$ : then

$$
x+p=\frac{a}{3 p} \quad \ldots \ldots \ldots \ldots \ldots \ldots \ldots
$$

